\title{
Deletion of the UL21 gene in Pseudorabies virus results in the formation of DNA-deprived capsids: an electron microscopy study
}

\author{
Frans WAGENAAR ${ }^{\mathrm{a}}$, Jan M.A. POL ${ }^{\mathrm{a} *}$, Niels DE WIND ${ }^{\mathrm{b}}$, \\ Tjeerd G. KIMMAN ${ }^{\mathrm{c}}$ \\ ${ }^{a}$ Institute of Animal Science and Health (ID-Lelystad), \\ Department of Avian Virology Houtribweg, PO Box 65, 8200 AB Lelystad, The Netherlands \\ $\mathrm{b}$ The Netherlands Cancer Institute, Division of Molecular Carcinogenesis, Plesmanlaan 121, \\ 1066 CX Amsterdam, The Netherlands \\ ${ }^{c}$ National Institute of Public Health and the Environment (RIVM), \\ Research Laboratory of Infectious Diseases, PO Box 1, 3720 BA, Bilthoven, The Netherlands
}

(Received 18 July 2000; accepted 9 October 2000)

\begin{abstract}
We studied the morphogenesis of three pseudorabies virus mutants lacking parts of the gene homologous to the UL21 gene of the herpes simplex virus type 1. The mutants were examined in an SK-6 cell-line, in an SK-6 cell-line expressing the UL21 gene product, in porcine lung alveolar macrophages (PLAM) and in porcine nasal mucosa explants. Although on SK-6 cells and PLAM, the virus-assembly and egress of mutant virus M155, lacking almost the entire UL21 gene, was similar to that of the rescued PRV mutant, M155 producing virions containing little or no DNA (Atype particles). Virus mutants M133 and M134 (lacking 23 and 232 amino acids respectively) produced more C-type particles. In SK-6 cells stably expressing the UL21-encoded protein, all mutants produced C-type particles. All mutants produced C-type particles in nasal mucosa explants, indicating that the UL 21-gene product is not essential for virus production in porcine tissue. These results support and extend previous work that indicated a role for the UL21 encoded protein in the packaging of newly replicated viral DNA.
\end{abstract}

electron microscopy / morphology / pseudorabies virus / UL21 gene

Résumé - La délétion du gène UL21 du virus de la maladie d'Aujeszky résulte dans la formation de capsides dépourvues d'ADN : étude en microscopie électronique. Nous avons étudié la morphogenèse de trois mutants du virus de la maladie d'Aujeszky (VMA) comportant des délétions dans l'homologue du gène UL21 du virus de l'herpes simplex de type 1. Les mutants ont été examinés dans une lignée cellulaire SK-6, dans une lignée SK-6 exprimant le produit du gène UL21, dans des

* Correspondence and reprints

Tel.: (31) 320238238; fax: (31) 320238668; e-mail: j.m.a.pol@id.wag-ur.nl 
macrophages alvéolaires de poumon de porc (MAPP), et dans des explants de muqueuse nasale de porc. Bien que dans les cellules SK-6 et les MAPP 1'assemblage et la sortie du virus mutant M155, à qui il manquait la presque totalité du gène UL21, étaient similaires à celles du mutant du VMA récupéré, ce mutant produisait des virions contenant peu ou pas du tout d'ADN (particules de type A). Les virus mutants M133 et M134 (à qui il manquait 23 et 232 acides aminés respectivement) produisaient plus de particules de type C. Dans les lignées cellulaires SK-6 exprimant de manière stable la protéine codée par UL21, tous les mutants ont produit des particules de type C. De même, tous les mutants ont produit des particules de type $C$ dans les explants de muqueuse nasale, indiquant que le produit du gène UL21 n'est pas essentiel pour la production de virus dans les tissus porcins. Ces résultats sont en accord avec les travaux précédents et renforcent l'idée que la protéine codée par UL21 joue un rôle dans l'empaquetage de l'ADN viral nouvellement répliqué.

microscopie électronique / morphologie / virus de la maladie d'Aujeszky / gène UL21

\section{INTRODUCTION}

Pseudorabies virus (PRV; synonyms suid herpesvirus type 1 and Aujeszky's disease virus), a member of the Alphaherpesvirinae subfamily, causes economically important disease of pigs. Pigs are the natural host of PRV, although many other animal species can be infected, usually with a fatal outcome [29]. Like all herpesviruses, PRV has an envelope surrounding a capsid of approximately $100 \mathrm{~nm}$ in diameter, which contains the double stranded DNA [14].

During packaging, concatameric viral DNA is cleaved and subsequently packaged into the preformed capsids [20, 26] yielding capsids with electron dense cores [16, 17, 20, 22, 25, 28]. According to Booy et al. [5] viral DNA is packed as locally ordered, liquid-crystalline, parallel packings of DNA duplexes. Next, the capsids adhere at virally induced patches in the inner nuclear membrane, and become enveloped by a budding process at the inner nuclear membrane. Complete virions appear in the perinuclear space, followed by cytoplasmic transport and budding at the outer nuclear membrane [20].

Based on biochemical data, de Wind et al. [6] suggested that the UL21 gene product has a regulatory or accessory role in the processing of viral DNA. In this process that is linked to encapsidation, concatemers of viral DNA are cleaved to unit-length linear DNA molecules. De Wind et al. [6] showed that a UL21 deletion mutant hardly produced any processed (1.1 kbp) viral DNA. A mutant virus containing part of the UL21 gene produced an intermediate amount of processed (1.1 kbp) viral DNA [6].

The UL21 gene is situated in the BamHI fragment 4 (Fig. 1). According to Lomniczi et al. [13] BamHI fragment 4 appears to encode only four genes, all of which are involved in nucleocapsid assembly. Baines et al. [2] reported that the UL21 gene is dispensable for growth in cells, however they found a 3- to 5-fold lower virus yield in human embryonic lung cells, compared to Vero cells.

To study the effect of (partial or total) UL21 deletion on the morphogenesis and virus-host cell interaction, we investigated three UL21 deletion mutants and a rescued PRV mutant on the SK-6 cell-line, porcine lung alveolar macrophages (PLAM), and porcine nasal mucosa.

\section{MATERIALS AND METHODS}

\subsection{Mutants}

We tested PRV UL21 mutants M133 (B35), M134 (B9), M155 (B59) and M156 [6] (Fig.1). M133 has an oligonucleotide insertion at the $\mathrm{C}$-terminus at amino acid position 500, lacking a minor part of the UL21 gene. M134 has an oligonucleotide 
UL $\quad$ IR US TR

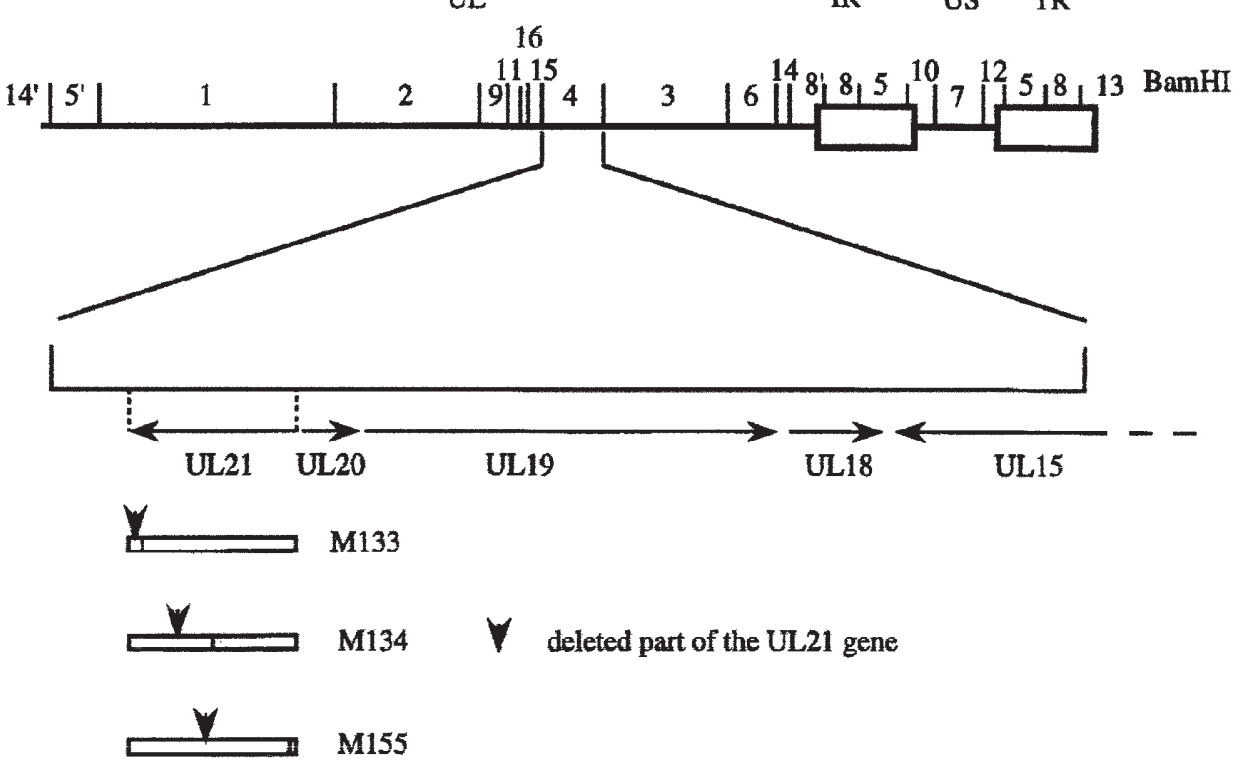

Figure 1. Physical map of the PRV genome (upper line). Open rectangles represent the internal $\left(\mathrm{I}_{\mathrm{R}}\right)$ and terminal $\left(\mathrm{T}_{\mathrm{R}}\right)$ repeat sequences which divide the genome into the $\mathrm{U}_{\mathrm{L}}$ and $\mathrm{U}_{\mathrm{S}}$ regions. Bam $\mathrm{HI}$ fragment 4 is enlarged to show the genes and their transcriptional directions (arrows) from [6,11].

insertion at amino acid 291, and lacks an intermediate part of the UL21 gene. M155 has an oligonucleotide insertion at amino acid 4 and lacks almost the entire UL21 gene. M156 was generated by marker rescue of M155 after cotransfection of a cloned $3.1 \mathrm{~kb}$ subcloned EcoRI-BamHI fragment from insertion mutant B33 [7] and contains all 523 amino acids. The virulence of these mutants is $262 \pm 25,145 \pm 4,54 \pm 8$ hours to death for M133, M134 and M156 respectively $[6,7]$.

\subsection{Cells}

Mutants were tested in SK-6 cell-line cultures [10] expressing the UL21 protein (SK-6-69), PLAM and porcine nasal mucosa explants.
The SK-6-69 cell-line was generated by stably transfecting SK-6 cells with vector pRC/CMV (Invitrogen, Groningen, the Netherlands) expressing the UL21 gene under control of the immediate early promoter of the cytomegalovirus.

PLAM were obtained from the lungs of 6-week-old SPF pigs from the herd of the ID-Lelystad (Institute for Animal Science and Health, the Netherlands) [27].

Nasal mucosa explants were collected from the same animals [16].

\subsection{Experimental protocol}

SK-6, SK-6-69, and PLAM cell cultures were grown on carbon-coated coverslips $(9 \times 35 \mathrm{~mm})$ in $35 \mathrm{~mm}$ plastic macro plates 

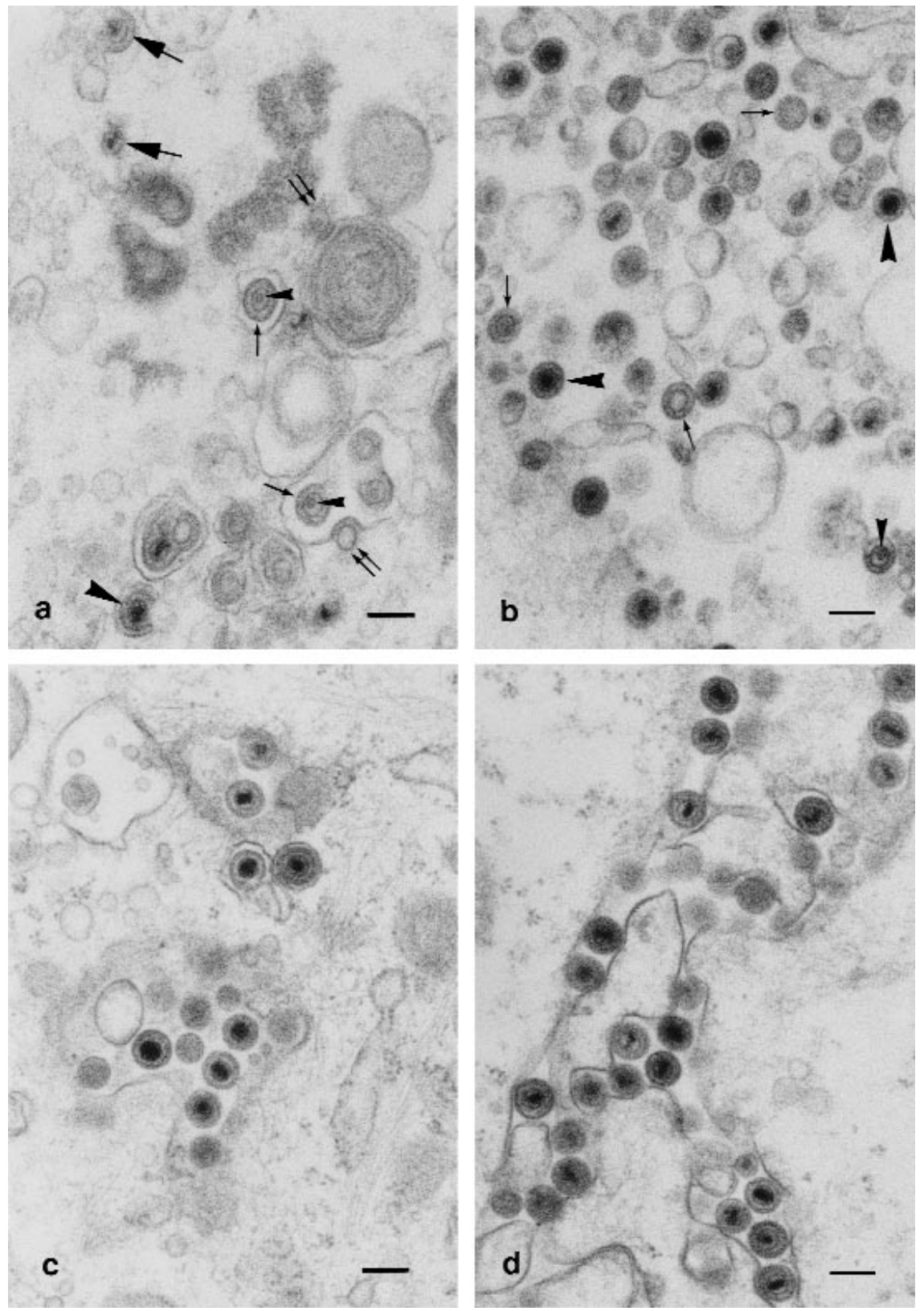

Figure 2. Electron micrographs of SK-6 cells, 16 hours after infection with the mutant PRV-M155, lacking a major part of the UL21 gene (a and b) or the rescued strain M156 (c and d).

(a) Empty (arrows) and incompletely DNA-filled virus particles (bold arrows) in the cytoplasm. In empty virus particles the spherical structure is clearly visible (arrowhead). Empty capsids bud easily at membranes of the smooth endoplasmic reticulum (double arrows). (b) In the extracellular space, empty, incompletely DNA-filled and completely DNA-filled virus particles are present. (c) Normal, completely DNA-filled virus particles in the cytoplasm and (d) in the extracellular space. Bar represents $200 \mathrm{~nm}$. 
(Corning Costar Europe, Badhoevedorp, the Netherlands) containing Earle minimal essential medium with $10 \%$ foetal calf serum and antibiotics as described previously [18]. At 9 and 16 hours post-infection (h.p.i.) with mutant virus strains (multiplicity of infection 1 ), the cultures were fixed with a cold fixative, containing osmium tetroxide and glutaraldehyde, by microwave irradiation, dehydrated and embedded in resin according to Wagenaar et al. [24].

Nasal mucosa explants were collected and treated as described previously [18]. Because PRV propagates in explants slower than in cell-lines, we studied the morphogenesis and viral infiltration at 24 h.p.i. and 48 h.p.i.

Nasal mucosa explants were processed according to Wagenaar et al. [24] as described above.

\subsection{Morphometry}

In the nucleus of the cell, viral capsids are assembled and subsequently filled with viral DNA. Next the nucleocapsids appear in the cytoplasm. Once in the cytoplasm, the nucleocapsids are in an end-state and filling with viral DNA is not possible anymore. After examining at least 100 infected cells to assess that the observed morphogenesis was generally identical, 25 cells were randomly assigned. In these cells, the extracellular virus structures and those in the cytoplasm were counted and expressed as a percentage of the total virus structures.

\section{RESULTS}

In SK-6 cells and in PLAM, viral capsids readily became enveloped at membrane structures and were detected in the extracellular space, irrespective of their DNA contents (Fig. 2). In the nuclei of infected cells, empty capsids and capsids completely or partially filled with DNA were present in equal numbers. The morphogenesis of the mutant strains M155, M133, and M134 differed from the rescued mutant M156.

Table I. Number of virus particles in the cytoplasm adhering to the cell surface of infected SK-6 cells, porcine lung alveolar macrophages (PLAM), SK-6-69 cells and epithelial cells of porcine nasal mucosa explants $(n=25)$.

\begin{tabular}{|c|c|c|c|c|}
\hline \multirow[b]{2}{*}{ Cell culture } & \multicolumn{4}{|c|}{$\begin{array}{c}\text { Virus type } \\
\text { (deletion size in no. of amino acids) }\end{array}$} \\
\hline & $\begin{array}{c}\text { M133 } \\
(23)\end{array}$ & $\begin{array}{l}\text { M134 } \\
(232)\end{array}$ & $\begin{array}{l}\text { M155 } \\
(519)\end{array}$ & $\begin{array}{l}\text { M156 } \\
(0)\end{array}$ \\
\hline $\begin{array}{l}\text { SK-6 } \\
\text { Number of virus particles } \\
\text { Number of empty capsids }(\%)\end{array}$ & $\begin{array}{c}415 \\
18(4)\end{array}$ & $\begin{array}{c}341 \\
63(18)\end{array}$ & $\begin{array}{c}1058 \\
581(55)\end{array}$ & $\begin{array}{c}318 \\
2(<1)\end{array}$ \\
\hline $\begin{array}{l}\text { PLAM } \\
\text { Number of virus particles } \\
\text { Number of empty capsids (\%) }\end{array}$ & $\begin{array}{l}264 \\
9(3)\end{array}$ & $\begin{array}{c}176 \\
41(23)\end{array}$ & $\begin{array}{c}168 \\
83(49)\end{array}$ & $\begin{array}{c}217 \\
1(<1)\end{array}$ \\
\hline $\begin{array}{l}\text { SK-6-69 } \\
\text { Number of virus particles } \\
\text { Number of empty capsids (\%) }\end{array}$ & $\begin{array}{c}901 \\
8(<1)\end{array}$ & $\begin{array}{c}954 \\
5(<1)\end{array}$ & $\begin{array}{c}1178 \\
10(<1)\end{array}$ & $\begin{array}{l}1247 \\
8(<1)\end{array}$ \\
\hline $\begin{array}{l}\text { Nasal mucosa explants } \\
\text { Number of virus particles } \\
\text { Number of empty capsids (\%) }\end{array}$ & $\begin{array}{c}384 \\
3(<1)\end{array}$ & $\begin{array}{c}616 \\
4(<1)\end{array}$ & $\begin{array}{c}369 \\
1(<1)\end{array}$ & $\begin{array}{c}490 \\
4(<1)\end{array}$ \\
\hline
\end{tabular}


Mutant strain M155, lacking 519 of the 523 amino acids, mainly showed A-particles (empty capsids), B-particles (incompletely DNA-filled particles) and only a few completely DNA-filled C-particles. In contrast, the rescued strain M156, containing all 523 amino acids, produced mainly C-particles. Mutant strain M133, lacking 23 of the 523 amino acids, showed a pattern that only slightly differed from M156; most progeny virus particles were $\mathrm{C}$-particles, but some were B-particles or A-particles.

Mutant strain M134, lacking 232 of 523 amino acids, produced an intermediate phenotype.

In SK-6-69 cells, which express the UL21 protein constitutively, the morphogenesis of all mutant strains was similar to the rescued strain M156 (Tab. I). Thus, the morphogenesis of UL21 negative mutants was normalised by expression of the UL21 gene in SK-6 cells.

In epithelial cells, tissue macrophages, and fibroblasts of the nasal mucosa explant cultures infected with UL21 mutants, we did not observe the aberrant morphogenesis that was present in SK-6 cells and PLAM, but all mutants (M133, M134, and M155) showed a wild-type-like morphogenesis like the rescued strain (M156) (Tab. I). At 24 h.p.i. all mutant strains had infected epithelial cells and had passed the basal lamina. The virus spread into the stroma and the number of epithelial cells that contained viral antigens was similar for M133, M134, M155 and the rescued strain M156. At 48 h.p.i., the infection had invaded slightly deeper into the stroma (data not shown).

\section{DISCUSSION}

Biochemical data provided by de Wind et al. [6] and Gielkens and Peeters [8] showed that the UL21 gene product has a regulatory or accessory role in processing of viral DNA or in packaging of viral DNA.
To provide morphological evidence for these options we studied the morphogenesis of the PRV UL21 mutants mentioned by de Wind et al. [6]. To assess the influence of UL21 we compared the mutants with the rescued mutant M156.

The SK-6-69 cell cultures were used as a second method to confirm the role of UL21. To obtain more information about the role of UL21 gene products in the natural host, we studied all strains in porcine nasal mucosa explant cultures, because they closely mimic the in vivo situation $[16,25]$.

After infection of SK-6 and PLAM with virus M155, lacking almost the entire UL21 gene, we mainly detected virus particles devoid of DNA outside of the nucleus. Interestingly, progressive inactivation of the UL21 gene correlated with decreased numbers of extranuclear C-particles. This morphological study corroborates biochemical data [6] showing that PRV-UL21 is involved in the cleavage of DNA and causes differences in DNA contents of the virus. Our observation that most of the virions are devoid of DNA agrees with the fact that the concatameric viral DNA is not efficiently processed into truncated viral DNA [6]. Capsid formation proceeds at a normal rate, resulting in a relative abundance of empty capsids (A-particles). The envelopment of capsids at cellular membranes efficiently produces empty enveloped virions. Empty enveloped virions have also been observed in studies using herpesviruses with deletions in other genes i.e. UL33, UL28, UL15, UL12 and UL6 [1, 3, 4, 15, 19, 21, 23]. Ward and Roizman [26] and Haarr and Skulstad [9] reviewed herpesvirus genes that are involved in processing and/or packaging. However, they did not mention the function of UL21. The UL21 gene product of both pseudorabies virus and herpes simplex virus type 1 was shown to be a capsid protein (reviewed in [14]).

In epithelial cells, tissue macrophages, and fibroblasts of the nasal mucosa explant cultures infected with UL21 mutants, we 
did not observe the aberrant morphogenesis that was present in SK-6 cells and PLAM. Instead, we found a morphogenesis of the wild-type virus. This morphogenesis was completely identical to previous results of morphogenesis studies in porcine nasal mucosa explants after the wild-type PRV infection [25].

Probably the combination of cells in nasal explants complements the lack of the UL21encoded protein. Thus, the marked decrease in viral replication of the UL21 negative virus, as observed by de Wind et al. [6] and Klupp et al. [12], is a feature of the mutant in isolated cells in culture.

A similar phenomenon was described by Baines et al. [2] when they compared viral replication of UL21 negative mutants in Vero cells (poor viral replication) with that in human embryonic lung cells (good viral replication).

The mutants tested in a single-step infection of SK-6 cells showed differences in plaque-morphology and titre. The mutant M155 (lacking almost the entire UL21 gene) replicated very poorly in SK-6 cells, yielding very tiny plaques [6]. Mutant M134 (lacking 232 aa of the UL21 gene), showed a 10 -fold reduction in titre compared with the rescued mutant [6]. In contrast, mutant M133 (lacking 23 amino acids of the UL21 gene), showed the same titre and plaque size as the rescued mutant (data not shown).

De Wind et al. [6] demonstrated by cellfractionation that the UL21 encoded protein in PRV is partially localised in the virion and in the nucleus of the cell and that UL21 is involved in cleavage of the viral DNA.

In conclusion, our results support the notion that the protein encoded by the UL21 gene also has a function in the packaging of viral DNA into the capsid.

\section{REFERENCES}

[1] Al-Kobaisi M.F., Rixon F.J., McDougall I., Preston V.G., The herpes simplex virus UL33 gene product is required for the assembly of full capsids, Virology 180 (1991) 380-388.

[2] Baines J.D., Koyama A.H., Huang T., Roizman B., The UL21 gene products of herpes simplex virus 1 are dispensable for growth in cultured cells, J. Virol. 68 (1994) 2929-2936.

[3] Baines J.D., Poon A.P.W., Rovnak J., Roizman B., The herpes simplex virus 1 UL 15 gene encodes two proteins and is required for cleavage of genomic viral DNA, J. Virol. 68 (1994) 8118-8124.

[4] Baines J.D., Cunningham C., Nalwanga D., Davison A., The UL15 gene of herpes simplex virus type 1 contains within its second exon a novel open reading frame that is translated in frame with the UL15 gene product, J. Virol. 71 (1997) 2666-2673.

[5] Booy F.P., Newcomb W.W., Trus B.L., Brown J.C., Baker T.S., Steven A.C., Liquid-crystalline, phage-like packing of encapsidated DNA in herpes simplex virus, Cell 64 (1991) 1007-1015.

[6] de Wind N., Wagenaar F., Pol J., Kimman T., Berns A., The pseudorabies virus homology of the herpes simplex virus UL21 gene product is a capsid protein which is involved in capsid maturation, J. Virol. 66 (1992) 7096-7103.

[7] de Wind N., Peeters B.P.H., Zijderveld A., Gielkens A.L.J., Berns AJ.M., Kimman T.G., Mutagenesis and characterization of a 41-kilobase-pair region of the pseudorabies virus genome: transcription map, search for virulence genes, and comparison with homologs of herpes simplex virus type 1, Virology 200 (1994) 784790.

[8] Gielkens A.L.J., Peeters B.P.H., Function of Aujeszky's disease virus proteins in virus replication and virulence, Acta Vet. Hung. 42 (1994) 227-241.

[9] Haarr L., Skulstadt S., The herpes simplex virus type 1 particle: structure and molecular functions, Acta Pathol. Microbiol. Immunol. Scand. 102 (1994) 321-346.

[10] Kasza L., Shadduck J.A., Christofinis G.J., Establishment, viral susceptibility and biological characteristics of a swine kidney cell line SK-6, Res. Vet. Sci. 13 (1972) 46-51.

[11] Klupp B.G., Kern H., Mettenleiter T.C., The virulence-determining genomic Bam $\mathrm{H} 1$ fragment 4 of pseudorabies virus contains genes corresponding to the $\mathrm{U}_{\mathrm{L}} 15$ (partial), $\mathrm{U}_{\mathrm{L}} 18, \mathrm{U}_{\mathrm{L}} 19, \mathrm{U}_{\mathrm{L}} 20$ and $U_{\mathrm{L}} 21$ genes of herpes simplex virus and a putative origin of replication, Virology 191 (1992) 900-908

[12] Klupp B.G., Lomniczi B., Visser N., Fuchs W., Mettenleiter T.C., Mutations affecting the UL21 gene contribute to avirulence of pseudorabies virus vaccine strain Bartha, Virology 212 (1995) 466-473.

[13] Lomniczi B., Watanabe S., Ben-Porat T., Kaplan A.S., Genome location and identification of func- 
tions defective in the Bartha vaccine strain of pseudorabies virus, J. Virol. 61 (1987) 796-801.

[14] Mettenleiter T.C., Aujeszky's disease (pseudorabies) virus: the virus and the molecular pathogenesis. State of the art, June 1999, Vet. Res. 31 (2000) 99-115.

[15] Patel A.H., Rixon F.J., Cunningham C., Davison A.J., Isolation and characterization of herpes simplex virus type 1 mutants defective in the UL6 gene, Virology 217 (1996) 111-123.

[16] Pol J.M.A., Quint W.V.G., Kok G.L., BroekhuijsenDavies J.M., Pseudorabies virus infections in explants of porcine nasal mucosa, Res. Vet. Sci. 50 (1991) 45-53.

[17] Pol J.M.A., Wagenaar F., Gielkens A., Morphogenesis of three pseudorabies virus strains in porcine nasal mucosa, Intervirology 32 (1991) 327-337.

[18] Pol J., Wagenaar F., The morphogenesis of Lelystad virus in porcine lung alveolar macrophages, Am. Assoc. Swine Practit. Newsletter 4 (1992) 29.

[19] Poon A.P.W., Roizman B., Characterization of a temperature-sensitive mutant of the UL15 open reading frame of herpes simplex virus type $1, \mathrm{~J}$. Virol. 67 (1993) 4497-4503.

[20] Roizman B., Sears A.E., Herpes simplex viruses and their replication, in: Fields B.N., Knipe D.M. (Ed.), Virology, Raven Press, New York, 1990, pp. 1795-1841.

[21] Shao L., Rapp L.M., Weller S.K., Herpes simplex virus 1 alkaline nuclease is required for efficient egress of capsids from the nucleus, Virology 196 (1993) 146-162.

[22] Smid B., Valicek L., Sabo A., Morphogenesis of Aujeszky's disease virus in pig lung macrophage cultures, Acta Vet. Brno 50 (1981) 79-87.
23] Tengelsen L.A., Pederson N.E., Shaver P.R., Wathen M.W., Homa F.L., Herpes simplex virus type 1 DNA cleavage and encapsidation require the product of the UL28 gene: isolation and characterization of two UL28 deletion mutants, J. Virol. 67 (1993) 3470-3480.

[24] Wagenaar F., Kok G.L., Broekhuijsen-Davies J.M., Pol J.M.A., Rapid cold fixation of tissue samples by microwave irradiation for use in electron microscopy, Histochem. J. 25 (1993) 719725.

[25] Wagenaar F., Pol J.M.A., Peeters B., Gielkens A.L.J., de Wind N., Kimman T.G., The US3encoded protein kinase from pseudorabies virus affects egress of virions from the nucleus, J. Gen. Virol. 76 (1995) 1851-1859.

[26] Ward P.L., Roizman B., Herpes simplex virus genes: the blueprint of a successful human pathogen, Trends Genet. 10 (1994) 267-274.

[27] Wensvoort G., Terpstra C., Pol J.M.A., ter Laak E.A., Bloemraad M., de Kluyver E.P., Kragten C., van Buiten L., den Besten A., Wagenaar F., Broekhuijsen J.M., Moonen P.L.J.M., Zetstra T., de Boer E.A., Tibben H.J., de Jong M.F., van't Veld P., Groenland G.J.R., van Gennep J.A., Voets M.T., Verheijden J.H.M., Braamskamp J., Mystery swine disease in the Netherlands: the isolation of Lelystad virus, Vet. Q. 13 (1991) 121130.

[28] Whealy M.E., Card J.P., Meade R.P., Robbins A.K., Enquist L.W., Effect of brefeldin A on alphaherpesvirus membrane protein glycosylation and virus egress, J. Virol. 65 (1991) 10661081.

[29] Wittmann G., Aujeszky's disease (Pseudorabies) in ruminants, in: Wittmann G. (Ed), Herpesvirus diseases of cattle, horses, and pigs, Kluwer Academic, Boston, 1989, pp. 163-175. 